\title{
DETERMINATION OF THE CRITERIA OF DEFORMATION IN A SPECIAL LIMITING STATE
}

\author{
Nikolay N. Trekin ${ }^{1,2}$, Emil N. Kodysh', Sergey D. Shmakov ${ }^{2,3}$, \\ Ivan A. Terekhov ${ }^{2,3}$, Konstantin L. Kudyakov ${ }^{1,4}$ \\ ${ }^{1}$ National Research Moscow State University of Civil Engineering, Moscow, RUSSIA \\ ${ }^{2}$ Central Scientific Research and Project Experimental Institute of Industrial Buildings and Constructions, Moscow, \\ RUSSIA \\ ${ }^{3}$ Russian University of Transport" (MIIT), Moscow, RUSSIA \\ ${ }^{4}$ JSC Research Center of Construction, NIIZHB named after A. A. Gvozdev, Moscow, RUSSIA
}

\begin{abstract}
Constructive measures taken to ensure the integrity of the entire building or its part in emergency situations with design based on the existing criteria of the limiting state method leads to a significant increase of the construction cost. One of the ways to reduce additional costs of construction while the protection design against progressive collapse is the possible use of additional reserves of deformability of load-bearing elements. It leads to redistribution of loads and the use of non-destroyed structures. It also leads to possible changes of limiting states in non-standard emergency design situations, taking into account the peculiarities of the operation of structures in a special limiting state at a stage close to destruction. In the GOST 27751-2014 «Reliability for constructions and foundations. General principles» calculated states of the first and second groups of limiting states are given, and for a special limiting state only the area of its permissible application is indicated. The work of reinforced concrete structures at the stage close to the depletion of the load-bearing capacity is little reflected in the scientific and technical literature; the work of reinforced concrete structures at the unloading stage due to the redistribution of forces is represented in single publications. The article presents theoretical studies based on experimental data on the deformation of bent reinforced concrete beam elements at a stage close to the maximum load-bearing capacity and at the stage of unloading up to the transformation of a structural element into a mechanism. The influence of the longitudinal reinforcement, the class of reinforcement, prestressing and the concrete strength on the deformation of reinforced concrete bending elements is considered in the article. The research of the behavior of structural elements continuation at this stage is relevant and contributes to the development of economical and rational design solutions for protection against progressive collapse and in the design of earthquake-resistant buildings.
\end{abstract}

Keywords: Protection against progressive collapse, special limiting state, deflections, partial destruction of sections, ultimate deformations of concrete, special limiting state criteria

\section{К ВОПРОСУ ОПРЕДЕЛЕНИЯ КРИТЕРИЕВ ДЕФОРМАТИВНОСТИ В ОСОБОМ ПРЕДЕЛЬНОМ СОСТОЯНИИ}

\author{
Н.Н. Трекин ${ }^{1,2}$, Э.Н. Кодыш ${ }^{2}$, С.Д. Шмаков ${ }^{2,3}$, И.А. Терехов ${ }^{2,3}$, \\ К.Л. Кудяков ${ }^{1,4}$ \\ ${ }^{1}$ Национальный исследовательский Московский государственный строительный университет, г. Москва, РОССИЯ \\ ${ }^{2}$ Центральный научно-исследовательский и проектно-экспериментальный институт промышленных зданий и \\ сооружений» (ЦНИИПромзданий), г. Москва, РОССИЯ \\ ${ }^{3}$ Российский университет транспорта (МИИТ), г. Москва, РОССИЯ \\ ${ }^{4}$ НИИЖБ им. А.А. Гвоздева АО «НИЦ «Строительство», г. Москва, РОССИЯ
}

\begin{abstract}
Аннотация. Конструктивные меры, принимаемые для обеспечения целостности всего здания или его части в аварийных ситуациях при проектировании на основе существующих критериев метода предельных состояний приводит к существенному росту стоимости строительства. Одним из способов снижения дополнительных затрат в строительстве при проектировании защиты от прогрессирующего обрушения является возможное расширение использования резервов деформативности несущих элементов, приводящее к большему перераспределению усилий и включению в работу неразрушенных конструкций. Это приводит к возможности изменения границ предельных
\end{abstract}


состояний в нестандартных аварийных расчетных ситуациях, учитывающее особенности работы конструкций в особом предельном состоянии на стадии близкой к разрушению. В ГОСТ 27751 «Надежность строительных конструкций и оснований» приведены расчетные состояния первой и второй групп предельных состояний, а для особого предельного состояния обозначена лишь область его допускаемого применения. В настоящее время в научно-технической литературе мало отражена работа железобетонных конструкций на стадии близкой к исчерпанию несущей способности, а работа железобетонных конструкций на стадии разгрузки за счет перераспределения усилий представлена единичными публикациями. В статье приведены теоретические исследования на базе экспериментальных данных деформирования изгибаемых железобетонных балочных элементов на стадии близкой к максимальной несущей способности, а также в стадии разгрузки вплоть до превращения конструктивного элемента в механизм. Рассматривается влияние количества продольного армирования, класса арматуры, предварительного напряжения, а также прочности бетона на деформирование железобетонных изгибаемых элементов. Продолжение исследований поведения конструктивных элементов на данной стадии является актуальным и способствует разработке экономичных и рациональных конструктивных решений для защиты от прогрессирующего обрушения и при проектировании сейсмостойких зданий.

Ключевые слова: защита от прогрессирующего обрушения, особое предельное состояние, прогибы, частичное разрушение сечений, предельные деформации бетона, критерии особого предельного состояния

\section{INTRODUCTION}

Analysis of world practice of design and operation of buildings and structures of the increased level of responsibility or of the normal level with a mass presence of people showed the need of protection against progressive collapse and to ensure the evacuation and preservation of the people in buildings and structures, to increase safety during the operation of objects. Since the end of the twentieth century, the resistance of load-bearing systems of buildings and structures to avalanchelike progressive collapse in emergency situations have been studied in the world design practice. The protection of buildings and structures from progressive collapse is relevant for newly designed, already constructed objects, and objects under reconstruction; it is regulated by the current normative documents in Russia, including [1] SP 385.1325800.2018 "Protection of buildings and structures against progressive collapse. Design Code. Basic statements".

\section{THE STATEMENT OF THE PROBLEM}

In Russia there is a legal requirement of protection design of the load-bearing objects from the avalanche-like progressive collapse in the hypothetical alternate removal of one load-bearing element. Such calculated situation is unlikely in reality, but if it occurs, it can cause complete or partial object destruction; additional measures excluding catastrophic consequences with the use of limiting states criteria for the operation stage can lead to additional economic costs [2]. It is possible to reduce these costs by using the reserves of load-bearing capacity of structures and buildings in a special limiting state.

It is known that the operation of individual structural elements beyond the normalized maximum load-bearing capacity is possible and it leads to significant redistribution of forces in statically indeterminate systems [3].

The most complete implementation of the reserves of strength and deformability is possible in loadbearing systems with a high degree of constructive interaction of all load-bearing elements and only when changing the criteria of limiting states. It is necessary to go beyond the standard requirements of the serviceability of reinforced concrete structures, rigidly limiting the crack opening and the appearing of sags. The low probability of the calculated situation and the serious consequences of the destruction of the building facilitate it. The local partial destruction of cross-sections and 
unit connections are must be allowed to keep the building as a whole. But it is necessary to use the unloading parts of the connecting elements, keeping the entire load-bearing system in a stable (equilibrium) state for a certain period.

According to SP 385.1325800.2018, "a special limiting state is the state of structures after exceeding the limit of load-bearing capacity for the first limiting state and deformability for the second limiting state, in which they do not fully fulfil the functional requirements. The further increase of loads and (or) impacts leads to their destruction". In this Building Code some criteria for a special limiting state of reinforced concrete and metal structures are suggested, they are designed based on the existing design practice, operation, experience in examining the technical condition of structures and experimental studies. Due to the limited amount of experimental data, the special limiting state criteria given in the current version of SP 385.1325800.2018 were adopted with some reserve to ensure the safety of building structures. The clarification of the criteria of the special limiting state is necessary to establish the possible further safe exceeding of the limits of the first and second limiting states; it is important for improving the efficiency of design solutions.

\section{EXPERIMENTAL STUDIES}

One of the important research areas is the study of the stress-strain state of bent reinforced concrete elements at the stages close to the maximum of load-bearing capacity and at the stage of destruction. For this purpose, the experiments (performed to solve other problems) of Plotnikov A. I. [5], Gushcha Yu. P. [6], Tamov M. A. [7] were studied in the article.

The diagrams below show the values of relative deflections of bent reinforced concrete elements in sections with the maximum bending moment, depending on the degree of loading (Fig. 1-3). The results of tests of four series of reinforced concrete beam elements differing in the content of longitudinal stretched reinforcement are presented in the paper [5]. At the same time, one of the samples of each series at the area of pure bending (the middle third of the span) had no longitudinal compressed reinforcement and clamps. In total, 12 beams were manufactured and tested. The crosssection was $100 \times 180 \mathrm{~mm}$ and the length was 2000 $\mathrm{mm}$. The beams were reinforced with A400 steel (AIII-35GS). Concrete $\mathrm{Rb}=27.1 \mathrm{MPa}$.

Based on the data presented in Fig. 1, samples without longitudinal compressed reinforcement were destroyed more intensively and deflections at the level of $0,7 \mathrm{Mult}$ were on average 1/70 of the span L. The longitudinal reinforcement in the compressed area of normal cross-section increases the resistance to the load after the destruction of the compressed area of concrete and deformability before turning the beam structure into a mechanism, it corresponds to the deflections $1 / 40$ of the span. At the same time the maximum deformability before the structural destruction varies inversely with the amount of stretched reinforcement and for samples with a reinforcement coefficient $\mu=1.95-2.5 \%$ and is $1 / 50$ of the span. The increased longitudinal reinforcement of the stretched area of the bent element leads to its rigidity increase, an increase of the compressed area of concrete and decrease of the deformability of the bent element.

Analyzing the diagrams presented in Fig. 2 , we can see that using thermally hardened tensile reinforcement of AIV class, structural deformability of plastic stage is reduced to $30 \%$ in comparison with similar constructions of AIV regular class. Prestressing of stretched reinforcement structures increases its general rigidity and crack resistance. Also it leads to a decrease of the maximum values of deflections up to $15 \%$ in comparison with analogues without prestressing.

The results of static and dynamic tests show that structures loading increase speed before the reduce the load-bearing capacity has little effect on the maximum values of deflections of truss elements (Fig. 3). Also there is an increase of the bearing capacity of dynamic loads up to $15 \%$. 


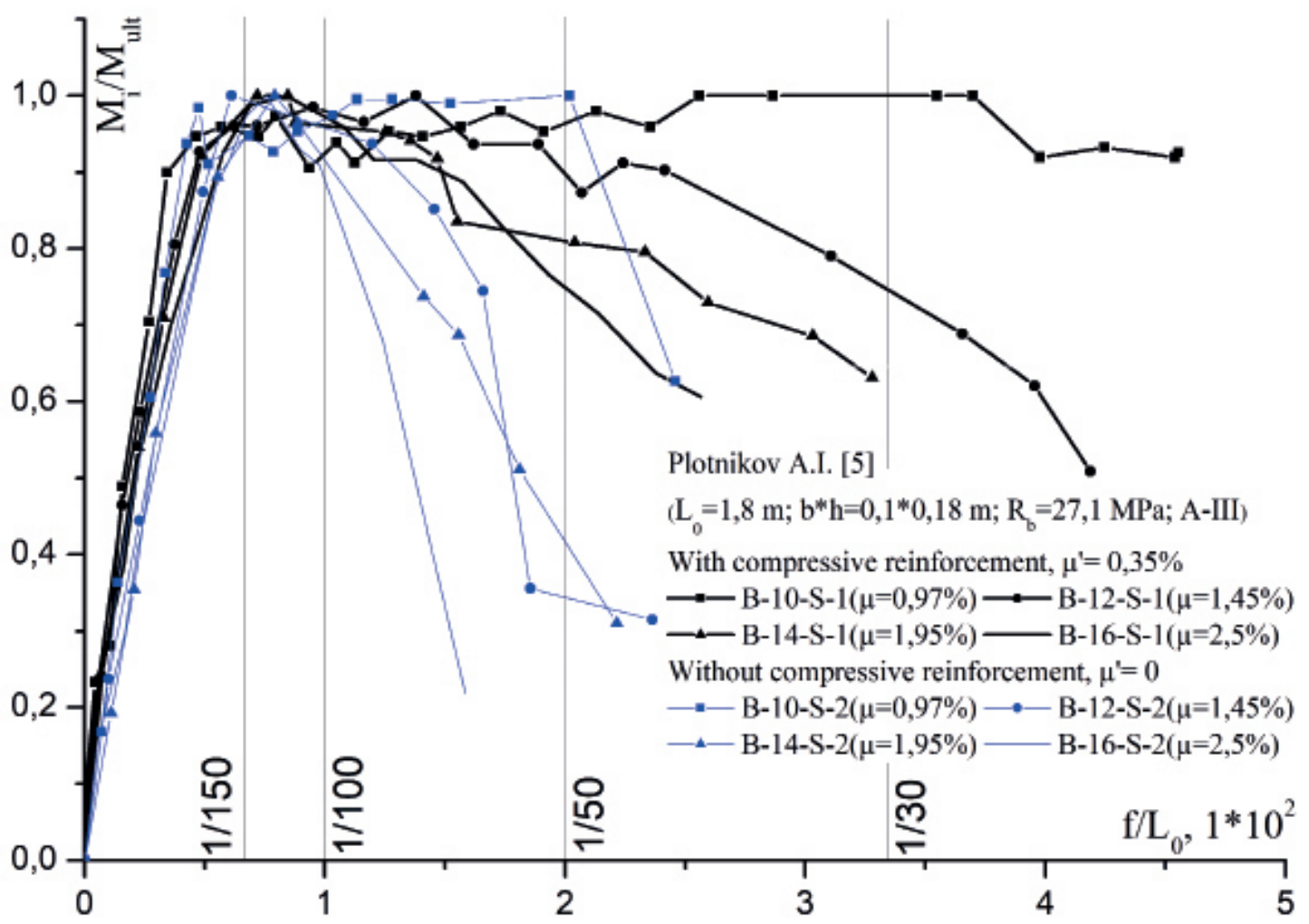

Figure 1. Diagrams of deformation of bent elements with different amount of longitudinal reinforcement (based on the works of Plotnikov A. I.)

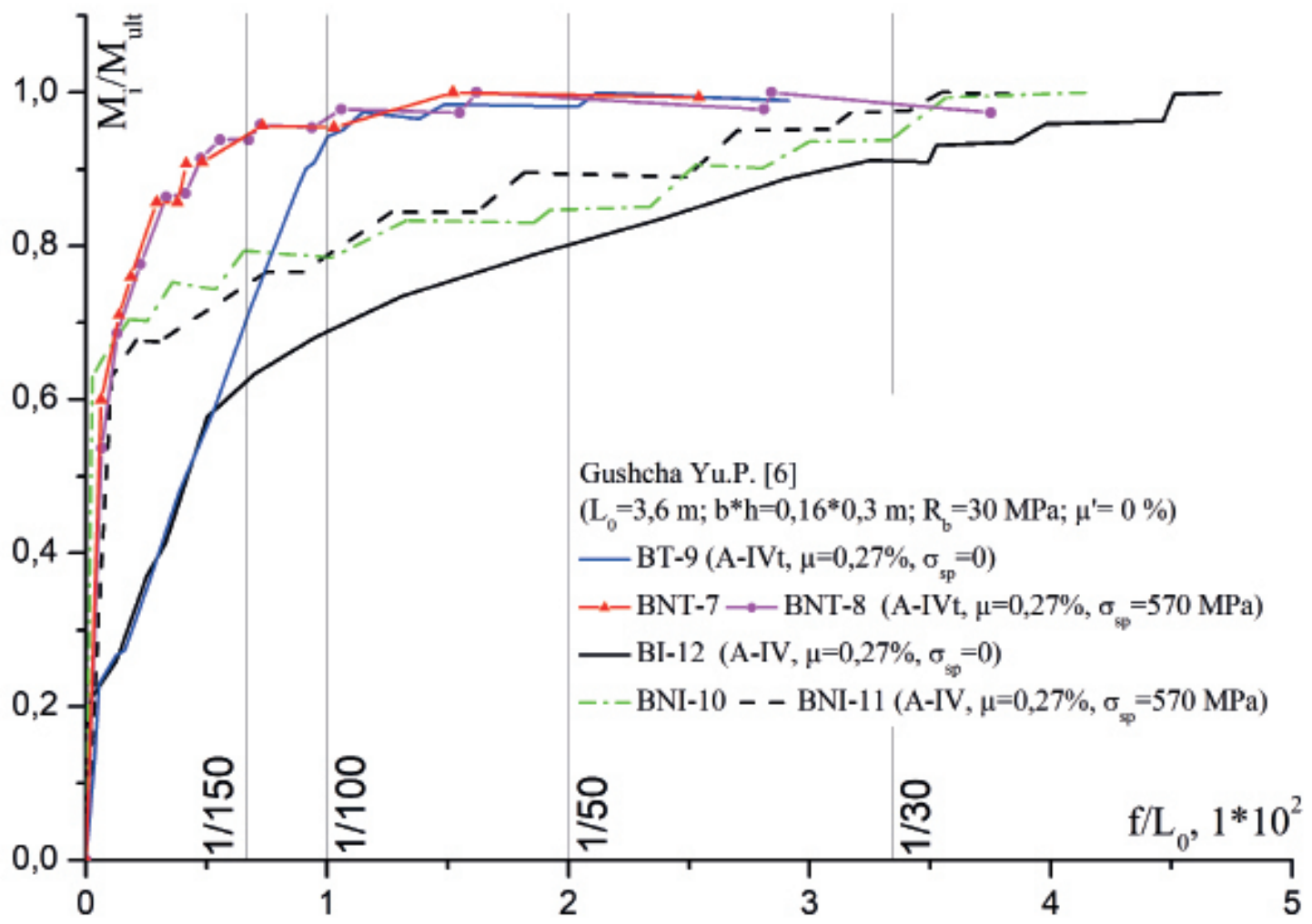

Figure 2. Diagrams of deformation of bending elements with conventional and thermally strengthened stretched reinforcement of AIV class, with and without prestressing 


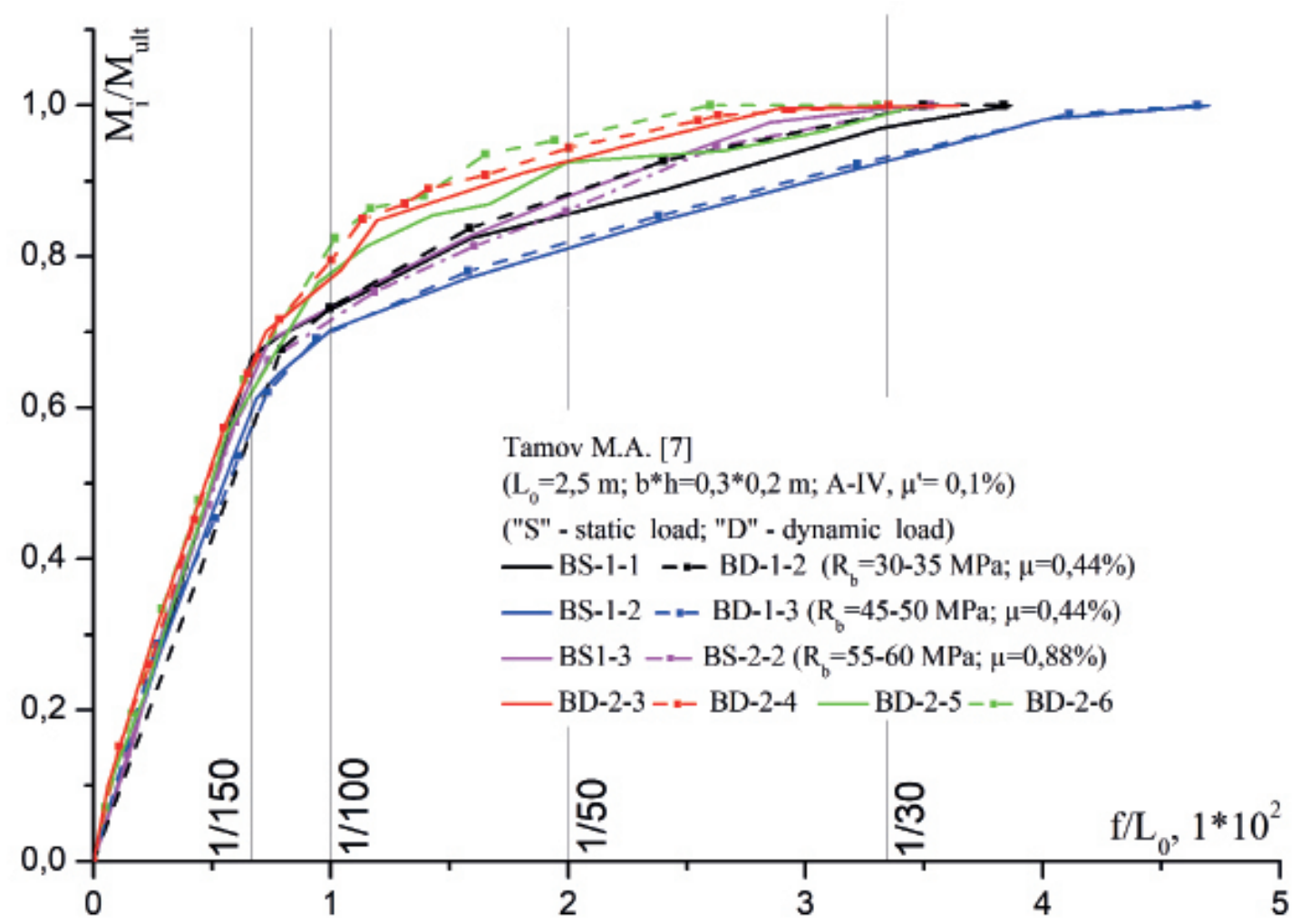

Figure 3. Diagrams of deformation of bent elements with different strength of concrete and the amount of longitudinal reinforcement, with static and short-term dynamic loads (based on works of Tamov M. A.)

THE PROSPECTS OF THE CRITERIA REFINEMENT FORASPECIALLIMITING STATE

The experimental data confirm the presence of reserves for the strength and deformability of structures in the calculation methods of the first and second groups of limiting states.

The present and prospective limits of the deformability criterion are presented in Table 1. The deformation test in compressed concrete showed that the approved limits in the SP 63.13330.2018 "SNiP 52-01-2003 Concrete and reinforced concrete structures. General provisions" and in European norms match the experimental data. It is not necessary to refine the value of maximum compressibility of concrete for a special limiting state.

The deformation test in stretched reinforcement showed the possibility of increasing the limits of the ultimate deformability of reinforcement, including the hardening stage for steels with a physical yield strength.

The largest reserves of the maximum deformability (deflections) are connected with the possibility of redistributing forces by using the adjacent structures in the process of force redistributing (deformation). To the greatest extent, this mechanism can be used in statically indeterminate structural systems. Additional testing allows to implement the principle of gradation of the criterion of limiting state of deformation (deflection) depending on the type of load-bearing structures and the ability to redistribute loads. It is used for monolithic buildings, prefabricated buildings, depending on the type of reinforcement (physical and conditional yield strength) and availability of the minimum allowable length of the bearing (embedment) area. 
Table 1. Current and prospective limiting state for deformability of reinforced concrete structures

\begin{tabular}{|c|c|c|c|}
\hline & $\begin{array}{l}\text { Criteria of I and II } \\
\text { group of limiting } \\
\text { states according to SP } \\
20.13330 .2016 \text {, SP } \\
63.13330 .2018\end{array}$ & $\begin{array}{l}\text { Criteria for a special } \\
\text { limiting state according } \\
\text { to SP } 385.1325800 .2018\end{array}$ & $\begin{array}{l}\text { Prospective data for the } \\
\text { special limiting state after } \\
\text { additional testing of the } \\
\text { bending elements }\end{array}$ \\
\hline $\begin{array}{l}\text { The relative } \\
\text { de formation } \\
\text { of the concrete } \\
\text { (below } 60), \varepsilon_{b 2}\end{array}$ & $0,035(100 \%)$ & $0,035(100 \%)$ & $0,035(100 \%)$ \\
\hline $\begin{array}{l}\mathrm{R} \text { e } 1 \text { a } \mathrm{t} i \mathrm{ve} \\
\text { deformations of } \\
\text { reinforcement } \\
\text { (with physical } \\
\text { yield strength), } \varepsilon_{s 2}\end{array}$ & $0,025(100 \%)$ & $0,033(132 \%)$ & $\begin{array}{c}0,035 \ldots 0,038 \\
(140 \% \ldots 152 \%)\end{array}$ \\
\hline $\begin{array}{l}\text { The relative } \\
\text { deformation of } \\
\text { the reinforcement } \\
\text { (with a nominal } \\
\text { yield strength), } \varepsilon_{s 2}\end{array}$ & $0,015(100 \%)$ & $0,020(133 \%)$ & $\begin{array}{c}0,022 \ldots 0,025 \\
(147 \% \ldots 167 \%)\end{array}$ \\
\hline $\begin{array}{l}\text { Deflections for } \\
\text { structures with } 1 \\
\text { span }\end{array}$ & $\begin{array}{l}\text { The m a x i m } \mathrm{m} \\
\text { d eflections and } \\
\text { displacements of } \\
\text { elements of buildings } \\
\text { and structures are not } \\
\text { specified in the present } \\
\text { and other normative } \\
\text { documents; vertical and } \\
\text { horizontal deflections } \\
\text { and displacements from } \\
\text { permanent, long-term } \\
\text { and short-term loads } \\
\text { must not exceed } 1 / 150 \\
\text { (100\%) or } 1 / 75 \% \text { of the } \\
\text { console overhang. }\end{array}$ & $\begin{array}{l}\text { The deflections of the } \\
\text { bending elements of } \\
\text { the structural system } \\
\text { for a special limiting } \\
\text { state, with the minimum } \\
\text { allowable length of the } \\
\text { bearing (embedment) } \\
\text { area must not exceed } \\
1 / 30 \text { (500\%) of span } \\
\text { length } 1, \text { excepting the } \\
\text { concrete structures } \\
\text { reinforced with high- } \\
\text { strength reinforcement } \\
\text { with nominal yield } \\
\text { strength, the deflection } \\
\text { of which must not } \\
\text { exceed } 1 / 50 \text { (300\%) of } \\
\text { the span length. }\end{array}$ & $\begin{array}{l}\text { The use of the gradation } \\
\text { by types of load-bearing } \\
\text { structures principle, taking } \\
\text { into account the ability to } \\
\text { redistribute forces, most } \\
\text { fully used in a statically } \\
\text { indeterminate structural } \\
\text { system, for example, for } \\
\text { monolithic buildings, the } \\
\text { deflection of the bending } \\
\text { element reinforced with a } \\
\text { physical yield point, if the } \\
\text { minimum permissible length } \\
\text { of the support (anchoring) } \\
\text { area can be } 1 / 25 . .1 / 20 \\
\text { (600\%...750\%) of the span } \\
\text { with reinforcement with a } \\
\text { conditional yield strength } \\
\text { - 1/50...1/40 (300\%...375\%) } \\
\text { length. }\end{array}$ \\
\hline
\end{tabular}




\section{CONCLUSION}

Due to the complexity of the reliable assess of stress state of cross sections at the stage of loadbearing capacity limit, and then at the destruction stage (when the hypothesis of flat sections is not tested) it is convenient to use the deformability criterion as the most predictable criterion of a special limiting state when ensuring limited operability of load-bearing reinforced concrete structural elements.

The analysis of normative documents, experimental and theoretical studies of bent reinforced concrete beam elements [8-10] showed that when fulfilling the normative requirements for the strength and deformability of reinforcement and concrete materials, geometric characteristics and the absence of structural defects, the structures have strength reserves up to $25 \%$, and deformability reserves up to $35 \%$. It is confirmed by comparing the experimental data with theoretical data obtained according to the calculations performed on the basis of regulatory documents. The research showed that when performing certain design requirements, including the use of reinforcement with a yield line in sections of the normative (optimal) percentage of reinforcement (not pre-reinforced), at the stage after reaching the limit of loadbearing capacity, there is a limited functional state of the element to reduce load-bearing capacity to $(0,5-0,9)$ Mult with the intensive cracks and deflections. The variation of results is due to the limited amount of available experimental data. It is found that at the stage of reducing the loadbearing capacity (unloading) of the bent element, the criteria for a special limiting state in the current version of SP 385.1325800.2018 are presented with some margin and help to fulfil the safety requirements, according to the current regulatory documents. The criteria are confirmed by the analysis of the works of Gushcha Yu. P. [6], Tamov M. A. [7] and Plotnikov A. I. [5]. After additional tests, due to the limited experimental data, the criteria can be refined by using the available reserves.
According to the authors, the operation of structures in a special limiting state can be used in earthquake-resistant construction.

\section{REFERENCES}

1. Federal Law No. 384-FZ "Technical Regulations on the Safety of Buildings and Structures" dated 30.12.2009

2. Kodysh E.N., Trekin N.N., Chesnokov D.A. The protection of multistory buildings from progressing collapse. Promyshlennoe i grazhdanskoe stroitel 'stvo [Industrial and Civil Engineering], 2016, no. 6, pp. 8-13. (In Russian)

3. Krylov S.M. Redistribution of forces in statically indeterminate reinforced concrete structures. M.: Publishing house of literature on construction, 1964, 170 p. (In Russian)

4. Trekin N.N. Kodysh E.N. Special limiting state of reinforced concrete structures and its normalization Promyshlennoe i grazhdanskoe stroitel 'stvo [Industrial and Civil Engineering], 2020, no. 5, pp. 4-9. (In Russian)

5. Plotnikov A.I. Dynamics of elastoplastic reinforced concrete beams under the action of intense short-term emergency loads: dis. ... Cand. tech. sciences. - M., 1994. - 375 p. (In Russian)

6. Gushcha Yu.P. Study of bending reinforced concrete elements while the operation of bar reinforcement in the elastoplastic stage: dis. ... Cand. tech. sciences. - M., 1967. - 142 p. (In Russian)

7. Tamov M.A. Investigation of concrete bending structures reinforced with steels of increased strength under short-term dynamic loading. M.: JSC NIIZhB. 1981 (In Russian)

8. Pankov E.N. Features of the work of bent concrete structures with compensated shrinkage under the action of transverse forces: dis. ... Cand. tech. sciences. - M, 2005. - 160 p. (In Russian)

9. Trekin D.N. Determination of deflections of bent reinforced concrete elements without 
prestressing on the basis of a deformation model. Molodoy uchenyy [Young Scientist], 2019. no 37. pp. 103-105. (In Russian)

10. Arslanbekov M.M. The study of strength, crack resistance and rigidity of reinforced concrete bending elements with mixed reinforcement: dis. ... Cand. tech. sciences. M, 2005. 166 p. (In Russian)

\section{СПИСОК ЛИТЕРАТУРЫ}

1. Федеральный закон №384-Ф3 «Технический регламент о безопасности зданий и сооружений» от 30.12.2009 г.

2. Кодыш Э.Н., Трекин Н.Н., Чесноков Д.А. Защита многоэтажных зданий от прогрессирующего обрушения // Промышленное и гражданское строительство. 2016. №6. С. 8-13.

3. Крылов С.М. Перераспределение усилий в статически неопределимых железобетонных конструкциях. М.: Издательство литературы по строительству 1964 г. 170 с.

4. Трекин Н.Н., Кодыш Э.Н. Особое предельное состояние железобетонных конструкций и его нормирование // Промышленное и гражданское строительство. 2020. № 5. C. 4-9.
5. Плотников А.И. Динамика упругопластических железобетонных балок при действии интенсивных кратковременных нагрузок аварийного характера: дис. ... канд. техн. наук. - М., 1994. - 375 с.

6. Гуща Ю.П. Исследование изгибаемых железобетонных элементов при работе стержневой арматуры в упруго-пластической стадии: дис. ... канд. техн. наук. - М., 1967. - 142 c.

7. Тамов М.А. Исследование железобетонных изгибаемых конструкций, армированных сталями повышенной прочности, при кратковременном динамическом нагружении. М.: АО НИИЖБ. 1981.

8. Паньков Е.Н. Особенности работы изгибаемых конструкций из бетона с компенсированной усадкой при действии поперечных сил: дис. ... канд. техн. наук. - М., 2005г. 160c.

9. Трекин Д.Н. Определение прогибов изгибаемых железобетонных элементов без предварительного напряжения на основе деформационной модели // Молодой ученый. 2019. №37. С. 103-105.

10. Арсланбеков М.М. Исследование прочности, трещиностойкости и жесткости железобетонных изгибаемых элементов со смешанным армированием: дис. ... канд. техн. наук. - М., 166 с.
Nikolay N. Trekin, advisor of RAASN, doctor of technical sciences, professor of the National Research Moscow State University of Civil Engineering; 26, Yaroslavskoe Shosse, Moscow, 129337, Russia. phones: +7 (495) 482-38-72. E-mail: otks@narod.ru

Emil N. Kodysh, Honored Scientist, Honorary Member of the RAASN, Doctor of Technical Sciences, Professor, Chief Researcher at Central Scientific Research and Project Experimental Institute of Industrial Buildings and Constructions; 46, bldg. 2, Dmitrovskoe Shosse, Moscow, 127238, Russia. phones: +7 (495) 482-35-65. E-mail: otks@narod.ru
Sergey D. Shmakov, post-graduate student, engineer of the department of structural systems №1 at Central Scientific Research and Project Experimental Institute of Industrial Buildings and Constructions; 46, bldg. 2, Dmitrovskoe Shosse, Moscow, 127238, Russia. phones: +7 (495) 48244-65. E-mail: otks@narod.ru

Ivan A. Terekhov, Candidate of Technical Sciences, Associate Professor of the Russian University of Transport (MIIT); 9, bldg. 9, st. Obraztsova, Moscow, 127994, Russia phones: +7 (499) 482-44-65. E-mail: terekhov-i@mail.ru 
Konstantin L. Kudyakov, Candidate of Technical Sciences, Associate Professor of the National Research Moscow State University of Civil Engineering; Head of sector of laboratory № 13 in the Research institute of reinforced concrete named after A.A. Gvozdev at JSC Research Center of Construction, 6, bldg. 5, 2nd Institutskaya st., Moscow, 109428, Russia phones: +7 (499) 174-77-24.

E-mail: konst_k@mail.ru

Трекин Николай Николаевич, советник РААСН, доктор технических наук, профессор ФГБОУ ВО «Национальный исследовательский Московский государственный строительный университет» (НИУ МГСУ); 129337, Россия, г. Москва, Ярославское шоссе, д. 26; начальник отдела конструктивных систем №1 АО «Центральный научно-исследовательский и проектно-экспериментальный институт промышленных зданий и сооружений» (ЦНИИПромзданий); 127238 Россия, Москва, Дмитровское шоссе, д.46, корп. 2. Тел.: +7 (495) 482-38-72. E-mail: otks@narod.ru

Кодыли Эмиль Наумович, заслуженный деятель науки, почетный член РААСН, доктор технических наук, профессор, главный научный сотрудник АО «Центральный научно-исследовательский и проектно-экспериментальный институт промышленных зданий и сооружений» (ЦНИИПромзданий); 127238 Россия, Москва, Дмитровское шоссе, д.46, корп. 2. Тел.: +7 (495) 482-35-65. E-mail: otks@narod.ru
Шмаков Сергей Дмитриевич, аспирант, инженер отдела конструктивных систем №1 АО «Центральный научноисследовательский и проектно-экспериментальный институт промышленных зданий и сооружений» (ЦНИИПромзданий); 127238 Россия, Москва, Дмитровское шоссе, Д.46, корп. 2; ассистент ФГАОУ ВО «Российский университет транспорта» (РУТ (МИИТ)), 127994, Россия, Москва, ул. Образцова, д. 9, стр. 9, Тел.: +7 (495) 482-44-65. E-mail: otks@narod.ru

Терехов Иван Александрович, кандидат технических наук, доцент ФГАОУ ВО «Российский университет транспорта» (РУТ (МИИТ)), 127994, Россия, Москва, ул. Образцова, д. 9, стр. 9; заведующий сектором отдела конструктивных систем №1 АО «Центральный научноисследовательский и проектно-экспериментальный институт промышленных зданий и сооружений» (ЦНИИПромзданий); 127238 Россия, Москва, Дмитровское шоссе, д.46, корп. 2; Тел.: +7 (495) 482-44-65. E-mail: terekhov-i@mail.ru

Кудяков Константин Львович, кандидат технических наук, доцент ФГБОУ ВО «Национальный исследовательский Московский государственный строительный университет» (НИУ МГСУ); заведующий сектором лаборатории № 13 НИИЖБ им. А.А. Гвоздева АО «НИЦ «Строительство; 109428, Россия, г. Москва, 2-я Институтская ул., д. 6. корп. 5. Тел.: +7 (499) 174-77-24. E-mail: konst_k@mail.ru 